\title{
Dinin Siyasete Etkisi Bakımından Vatikan- Moskova İlişkileri: Çarlık Rusyası Örneği
}

Şir Muhammed DUALI*

The Vatican-Moscow Relations with regard to the Religion's Influence on Politics: In the Case of Tsarist Russia

Citation/@: Dualı, Şir Muhammed, (2014). The Vatican-Moscow Relations with regard to the Religion's Influence on Politics: In the Case of Tsarist Russia, Milel ve Nihal, 11 (1), 71-89.

Abstract: This study is dealt with the Roman Catholic Church, which sees itself as the center of Christianity struggle to perform under pressure for the Russian Orthodox Church and meanwhile the Russian government. In this context, the popes used both political and religious authority for setting up hegemony on Moscow after that the Russians have chosen to be Orthodoxy instead of Catholicism. In particular, it will be examined the reasons and consequences of the endeavors of Roman Catholic Church for tying up the Russian Government in the name of Crusade alliance against Muslim threat. Finally, it's revised that the attitude of Roman Papacy in the face of that the tsarist Russia gradually turned into Empire in the context of the changing world and became a threat for Western world.

Key Words: Pope, Catholic Church, Moscow, Russian Orthodox Church, politics.

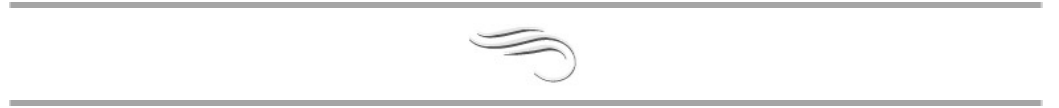

Atıf/C: Dualı, Şir Muhammed, (2014). Dinin Siyasete Etkisi Bakımından Vatikan-Moskova İlişkileri: Çarlık Rusyası Örneği, Milel ve Nihal, 11 (1), 71 89.

* Yard. Doç. Dr., Gaziosmanpaşa Üniversitesi, İlahiyat Fakültesi, Dinler Tarihi Anabilim Dalı [muhammed.duali@gop.edu.tr] 
Öz: Bu çalışma tarih boyunca kendisini Hıristiyanlığın merkezi olarak gören Roma Katolik Kilisesinin Çarlık Rusyası'ndaki Ortodoks Kilisesini ve aynı zamanda dönemin Rus devletini kendi etkisi altına alma mücadelesini konu edinmektedir. Bu çerçevede Rusların Katoliklik yerine Ortodoksluğu benimsemesini müteakiben Papaların hem siyasi hem de dini otoritesini kullanmak suretiyle Moskova üzerinde tahakküm kurma girişimleri örnekler ışığında incelenmektedir. Özellikle İstanbul'un Osmanlılar tarafından fethedilmesinin ardından Müslüman tehdidi karşısında haçlı ittifakı adı altında Rus yönetiminin Roma Kilisesi'ne bağlanma gayretlerinin neden ve sonuçları analiz edilmektedir. Son olarak da değişen dünya konjonktürü çerçevesinde Çarlık Rusya'sının bir imparatorluğa dönüşmesi ve giderek Batıyı tehdit eder hale gelmesi karşısında Roma papalığının takındığı tavır gözden geçirilmektedir.

Anahtar Kelimeler: Papa, Katolik Kilisesi, Moskova, Rus Ortodoks Kilisesi, siyaset.

\section{Giris}

“İsa: ‘Ne mutlu sana, Yunus oğlu Simun! Bu sırrı sana açan insan değil, göklerdeki babamdır. Ben de sana şunu söyleyeyim, sen Petrus'sun ve ben kilisemi bu kayanın üzerine kuracağım. Ölüler diyarının kapıları ona karşı direnemeyecek'”. ${ }^{1}$

Yukarıda bahsi geçen Yeni Ahit pasajını referans alan Katolik inancına göre, kilisenin başında bulunan Papa, Tanrı oğlu İsa'nın yeryüzündeki varisi konumundadır. Zira dünyadayken kilisenin başı konumunda olan İsa'nın, göğe çekilmeden önce kendine varis olarak havari Petrus'u bırakması, Katolik öğretisinin özünü oluşturmaktadır. Yine İncil'de yer alan bazı ifadeler, ${ }^{2}$ Roma Katolik Kilisesi'nin kendisini Hıristiyan dünyasının yegâne önderi ve evrensel Hıristiyan inancının tek temsilcisi olarak görmesine yol açmıştır. Dolayısıyla da tarih boyu tüm Hıristiyan kiliselerini kendi önderliği altında birlik ve bütünlük içerisinde tutmaya gayret sarf etmiştir. Ancak VI. yüzyıl içerisinde imparatorluğun başkentinin Batı Roma'dan Doğu Roma'ya (Bizans) taşınmasıyla alevlenen önderlik mücadelesi, 1054 yılında Hıristiyan dünyasının Doğu ve Batı olmak üzere ikiye ayrılmasıyla sonuçlanmıştır. Ancak Katolik Kilisesi kendini Roma'nın tek varisi olarak görmekten vazgeçmemiş ve diğer

\footnotetext{
Matta, 16: 17-19. Luka, 22: 32-32

Örneğin Yuhanna, 17:22-23'te "Yalnız onlar için değil, onların sözüyle bana iman edenler için de istekte bulunuyorum, hepsi bir olsunlar. Baba, senin bende olduğun ve benim sende olduğum gibi, onlar da bizde olsunlar. Dünya da beni senin gönderdiğine iman etsin. Bana verdiğin yüceliği onlara verdim. Öyle ki, bizim bir olduğumuz gibi bir olsunlar".
} 
Dinin Siyasete Etkisi Bakımından Vatikan-Moskova İlişkileri: Çarlık Rusyası Örneŏi tüm kiliseleri yeniden kendi yönetimi altına almak maksadıyla hem teolojik hem de siyasi argümanlar ortaya koymaya çalışmıştır. ${ }^{3} \mathrm{Bu}$ çerçevede Roma papalığının dini ve politik açıdan kontrol altına almak istediği bölge ve kiliselerin başında Romanya (Transilvanya), Moldavya ve özellikle de X. yüzyıldan itibaren Ortodoks inancını benimseyen Rusya gelmektedir. Papalığın hem siyasi hem askeri hem de ekonomik olarak altın çağını yaşadığ XIII. yüzyıllar bu çabanın etkin bir biçimde yürütülmesine olanak sağlamıştır.

İstanbul'un Müslümanlar tarafından fethedilmesinden sonra Roma Katolik Kilisesinin başına gelen hemen her papa, Rusya, dolayısıyla da Rus Ortodoks Kilisesiyle daha da yakından ilgilenmiş ve hem teolojik hem de siyasi gerekçelerle Rus Kilisesini etki altına almaya çalışmıştır. Bu bağlamda Papaların tarihi süreç boyunca Rusya'yla ilgilenmelerinin temel iki nedeninin olduğunu söylemek mümkündür. Bunlardan ilki giderek büyüyen ve güçlenen Rusya'nın Osmanlıya karşı oluşturulacak muhtemel haçlı ittifakında yer almasını sağlamak, ikincisiyse Rus Ortodoks Kilisesi'nin papanın üstünlüğünü kabul ederek onun yönetimi altına girmesini temin etmektir. Ancak Papaların birinci şartın gerçekleşebilmesini, Rus Kilisesinin papanın üstünlügünü kabul etmesini ve onun kontrolü altına girmesini öngören ikinci şarta bağlaması, genellikle ilk isteğin gerçekleşmesine engel teşkil etmiştir.

3 Roma Papalığının bu iddiasını reddeden Ortodoks Kilise yetkilileri, yine Yeni Ahit' in Korintlilere Mektup bölümünde kilisenin İsa'nın vücuduna benzetilmesi ve "Sizler Mesih'in bedenisiniz, bu bedenin ayrı ayrı üyelerisiniz. Beden bir olmakla birlikte birçok üyeden oluşur ve çok sayıdaki bu üyelerin hepsi tek bir beden oluşturur. Mesih de böyledir" denmesini delil olarak öne sürmüştür. Bu pasajları yorumlayan kilise babalarından John Chrysostom, (ö. 407) burada anlatılmak istenenin çeşitli uzuvların bir bedene ait olduğu değil, aksine bir olan bedenin çeşitli uzuvlarından müteşekkil olmasıdır demektedir. Yine ona göre eğer çeşitli organlar olmasa doğal olarak vücudun mevcudiyetinden söz etmek mümkün olmayacaktır. Dolayısıyla uzuvlar (kiliseler) arasında herhangi bir üstünlük ve bir diğerine tahakküm söz konusu değildir. Roma imparatorluğunun 395 y1lında Doğu ve Batı Roma olmak üzere ikiye ayrılmasını müteakip ortaya çıkan teolojik tartışmalar neticesinde geliştirilen bu doktrin, zamanla Rus Ortodoks Kilisesi tarafından da benimsenmiş ve papalık argümanlarına karşı kullanılmıştır. Bkz. John Chrysostom, Tvoreniya (Creations), c. X, Petersburg, 1904, s. 297-310. 


\section{Papalık Moskova İlişkilerinin Tarihi Seyri}

X. yüzyıldan itibaren şimdiki Ukrayna toprakları içerisinde tarih sahnesine çıkan ve giderek konumunu güçlendirmeyi başaran Kiev Rus Derebeyliği, hem Batı hem de Doğu komşularının dikkatinden kaçmamıştır. Bunların başında Katolik Roma Kilisesi ile Ortodoks Doğu Roma İmparatorluğu gelmektedir. Ayrıca bazı Rus kaynaklar Kiev Derebeyliği ile İdil Müslümanlarının ve Hazar Yahudilerinin de ilgilendiğini kaydetmektedir. ${ }^{4}$ Ancak coğrafi konum ve siyasi güç açısından daha etkin konumda olan Doğu Roma İmparatorluğu ve Roma Kilisesi, Kiev Derebeyliğiyle daha yakından ilgilenen iki güç olarak karşımıza çıkmaktadır. Nitekim her iki devlet, Hıristiyanlık üzerinden bölgeyi kontrol altına almayı hedeflemiş ve bu uğurda ciddi gayret sarf etmiştir. Bu çerçevede Papalık Kiev Derebeyliğini Alman Krallığı üzerinden etki altında tutmaya çalışmıştır. Bu konuda bilgi veren ilk Rus kroniği konumunda olan Eski Zamanların Anlatısı ${ }^{5}$, henüz putperest olan Kiev derebeyi Vladimir'e (ö. 1015) Katolikliği tebliğ etmek üzere Alman Krallığı üzerinden misyonerlerin gönderildiğini aktarmaktadır. ${ }^{6}$ Tarihi kayıtlar Papalığın bunca çabasına rağmen, Vladimir' in Katolikliği reddederek 988 yılı itibarıyla Doğu Roma İmparatorluğunun yoğun gayreti sonrası Ortodoksluğu resmi din olarak benimsediğini nakletmektedir. ${ }^{7}$

Tüm bu gelişmelere rağmen hemen hemen bütün Papalar, Slav toprakları üzerinde etkin olmak için bir takım faaliyetler yürütmeye devam etmiştir. Örneğin 1199 yılı itibarıyla çeşitli Rus beylerini Kiev etrafında birleştiren ve Macarlara karşı zafer elde eden dönemin Rus derebeyi Mstislavich Roman'a (ö. 1205) Papa III. İnnocentius ${ }^{8}$

4 Bkz. Lavrentevskaya Letopis, Laurentian Kronik, Rus Kronikler Kolleksiyonu, II. Baskı, c. I, 1926-1928, s. 60.

5 Eski Zamanların Anlatısı "Rusça; Повесть временных лет, Povest Vreminnkh Let," İlk Rus kroniği olarak bilinen bu metin 11. yüzyılın sonu-12. yüzyılın başlarında yaşamış ve azizlerin hayat öyküsünü kaleme almasıyla bilinen (Hagiography) Nestor tarafından yazıldığı tahmin edilmektedir. Bkz. A. A. Şahmatov, Razıskaniya o Drevneyşikh Russkih Letopisnıh Svodah, Petersburg, 1908, s s. 133-161.

6 O. M. Papov, Russkaya Tserkov v IX-XII veke, Prinyatie Hristianstva, Moskova, 1988, s. 196.

7 Papov, Russkaya Tserkov v IX-XII veke, s. 208.

8 Tüm zamanların en etkili papası olan İnnocentius 1198 yılında papalık koltuğuna oturmuş ve 1216 yılında ölene kadar papalık yapmıştır. Kralların meşruiyetinin 
Dinin Siyasete Etkisi Bakımından Vatikan-Moskova İlişkileri: Çarlık Rusyası Örneŏi (ö. 1216) tarafından elçiler gönderilmiştir. Rus Tarihçi V. Tatishev, Papalık elçisinin 1204 yılında Kiev'e ulaştığını ve Rus derebeyi Roman'a papalık kılıcını sunduğunu ancak Mstislavich Roman'ın bu teklifi geri çevirdiğini kaydetmektedir. ${ }^{9}$ Papanın Kiev derebeyliğine elçi göndererek onu Papalık otoritesini kabul etmeye davet ettiği tarihle, İstanbul'un IV. Haçlı Seferleri kapsamında (1200-1204) işgal edilişinin aynı döneme denk gelmesi dikkatlerden kaçmamaktadır. Zira bu tarihlerde Ortodoksluğun merkezi konumunda olan İstanbul'un Katoliklerin eline geçmesi ve Ortodoks patriğinin görevinden alınarak yerine Katolik bir papazın tayin edilmesi, Ortodoks inancına mensup Rus toplumunun Papalık otoritesini kabule zorlayabilirdi. Nitekim Rus Ortodoks Kilisesi hukuki açıdan İstanbul Kilisesi'ne bağlıydı ve İstanbul Kilisesi'nin papanın kontrolüne geçmesi bu süreci hızlandırabilirdi. Ancak görüldüğü kadarıyla dönemin Kiev Derebeyi Roman, Papalığın bu baskısına boyun eğmemiştir.

1242 yılı itibarıyla Moğol Tatar güçlerinin Kiev Derebeyliğine doğru ilerlemesini bir fırsat olarak gören dönemin Roma Papası IV. İnnocentius (ö. 1254) 1248 yılında iki kardinali Kiev Rus derebeyi Aleksander Nevsky’e (ö. 1263) göndererek Katolikliği kabul etmesi halinde Moğol Tatar akınına karşı yardım etme teklifinde bulunmuştur. Papanın bu teklifini değerlendiren Aleksandr; "bizler doğru inancın hangisi olduğunu iyi biliriz ve sizin teklifinizi kabul etmeyiz" diyerek reddetmiştir. Bu ve buna benzer birçok girişimin karşılıksız kalması sonrasında, 1351 yılında dönemin Papası VI. Klement (ö. 1352) önderliğinde Ruslara yönelik haçlı seferleri organize edilse de istenen sonuca ulaşılamamıştır. ${ }^{10}$

XV. yüzyıldan itibaren Papalıkla Rus Çarlığı arasında ilişkilerin iki nedenden dolayı yeniden canlandığını görmek mümkündür. Bunlardan ilki Çar III. İvan'la (ö. 1505) birlikte Rusya'nın güçlü bir devlete dönüşmeye başlaması, ikincisiyse İstanbul'un Müslümanlar tarafından fethedilmesidir. Yukarıda da bahsedildiği üzere Papalık,

ancak Papa tarafından taç giydirilmekle mümkün olacağını savunan Innocentius, kendisini "İsa'nın vekili" olarak tanımlamış ve papaların belki tanrı olmadıklarını ancak insan da olamayacaklarını dolayısıyla Tanrı ile insan arasında bir varlık olduklarını iddia etmiştir. Bu konuda geniş bilgi için bkz. Bekir Zakir Çoban, Geçmişten Günümüze Papalık, İnsan Yayınları, İstanbul, 2009, s. 110.

9 V. N. Tatishev, s. İstoriya Rossiyskaya, s Samih Drevneyshk Vremen, Kniga Tretiy, İmperatorsky Moskovsky Universitet, 1774, 345.

10 D. M. Tolstoy, Rimsky Katolisizm v Rossii, Tom Pervy, Petersburg, I, 1876, s. 6-8. 
Moğol-Tatar istilası sırasında Rusları destekleme şartını Katolik inancını kabule bağlamıştı. Ayrıca buna benzer bir teklifin Osmanlı tehdidiyle karşı karşıya kalan Doğu Roma İmparatorluğu için yapıldığ 1 bilinmektedir. Nitekim çaresiz kalan Doğu Roma İmparatorluğu 1439 yılında Floransa' da toplanan konseyde Papa'nın üstünlügüunü tanımak mecburiyetinde kalmıştır. Grek asıllı Metropolit İsidor (ö. 1462) bu konseyi Rus Ortodoks Kilisesi adına temsil etmiş ve dönemin Papası IV. Eugenius (ö. 1447) tarafından Letonya, Rusya ve Polonya Eyaletinin Papalık elçisi olarak görevlendirilmiştir. ${ }^{11} 1441$ 'in ilkbaharında Moskova'ya gelen İsidor, düzenlenen kilise ayini sırasında Papanın kiliselerin birleşmesiyle ilgili fermanını okuduktan sonra halkın tepkisiyle karşı karşıya kalmış ve tutuklanarak zindana atılmıştır. Bu gelişmeleri müteakiben toplanan Rus Ortodoks Kilise piskoposlar konseyinde Batı ve Doğu kiliselerinin birleşmesi kararı kınanmıştır. ${ }^{12}$ Dolayısıyla Papanın Rus Ortodoks Kilisesini kontrol altına alma girişimi bir daha başarısızlıkla sonuçlanmıştır. Papanın özel misyonu ile Rusya'ya gelen İsidor'un görevden azledilmesi, ikili arasında gerginliğe neden olmuşsa da 1453'te İstanbul'un fethedilmesiyle birlikte ilişkiler yeniden tesis edilmeye çalışılmıştır. Bu çerçevede 1471 yılında Papalık Rusya'ya elçi göndererek ilişkileri yeniden onarmaya gayret göstermiştir. Ayrıca Papa, Çar III. İvan'a Roma' da bulunan son Doğu Roma İmparatorunun yeğeni prenses Sofia Paleologue ile evlenme teklifinde bulunarak Rus çarını etki altına almaya çalışmıştır. ${ }^{13}$

Osmanlı İmparatorluğu'nun Avrupa'nın içlerine doğru ilerlemesi, Papalığ ciddi manada korkutmuştur. Bu bakımdan Osmanlıya karşı çeşitli ittifak arayışı içerisine giren Papalar, XVI. yüzyıl içerisinde yeniden Çarlık Rusyası'na yönelme ihtiyacı hissetmişlerdir. Bu çerçevede Papa X. Leo (ö. 1521) 1518 yılında Osmanlıya karşı bir haçlı seferi ilan etmiş ve Rusya'nın da desteğini almak için Çar III. Vasili İvanovich'e (ö. 1533) elçi göndererek Floransa anlaşmasını kabul etmesini ve Osmanlı karşıtı ittifakta yer almasını teklif etmiş-

11 Episkop Germogen, "Papstva i Pravoslavnaya Tserkov," Jurnal Moskovsky Patriarkhi, 4/1948, s. 34.

12 V. Nikonov, "Russkaya Pravoslavnaya Tserkov i Rim," Jurnal Moskovsky Patriarkhi, 3/1949, s. 26.

13 T. V. Zonova, Rossiya i İtaliya: İstoriya Diplomaticheskih Otnosheniy, Chast I, Moskova, 1998, s. 6. 
Dinin Siyasete Etkisi Bakımından Vatikan-Moskova İlişkileri: Çarlık Rusyası Örneŏi

tir. Lakin III. Vasili, istenen ittifaka olumlu baktığını ancak inanç konusunda Ortodoks geleneğine bağlı kalacağını ve Papa'nın üstünlüğünü kabul etmeyeceğini dile getirmiştir. ${ }^{14}$ Papa'nın Rusya'yı iknaya yönelik çabasının sürdüğü bir dönemde Almanya'da Martin Luther'in 95 maddelik bir bildiri yayınlayarak Papa'nın otoritesine karşı çıkması, planlanan haçlı seferini sekteye uğratmıştır. Nitekim bu aşamadan sonra Roma papası önderliğindeki Katolik kilisesi Luther'in öncülüğünde ortaya çıkan Protestanlıkla dolayısıyla da Protestanlığ1 benimseyen yöneticilerle mücadele etmek zorunda kalmıştır. ${ }^{15}$ O nedenle 1520'den 1550'ye kadar Papaların Moskova yönetimine yönelik bir girişimi söz konusu olmazken, 1545 yılında düzenlenen Trent Konsili'ne de hiçbir Rus kilise temsilcisi davet edilmemiştir.

Papalıkla Çarlık Rusyası arasında kopan ilişkiler 1550 yılında papa seçilen III. Julius'un (ö. 1555) girişimleriyle yeniden onarılmaya çalışılmışsa da dönemin Rus Çarı Korkunç İvan (ö. 1584) tarafından karşılıksız bırakılmıştır. Rus yöneticileri her ne kadar papalığın, "papanın üstünlüğünü tanıma" dayatmasına boyun eğmemiş olsalar da, bu durumun, Roma'nın Rus Ortodoks Kilisesine yönelik politikasında bir değişikliğe neden olmadığ1 görülmüştür. Zira Roma Katolik Kilisesi bir yandan giderek güçlenmekte olan Çarlık Rusya'sını Osmanlıya karşı muhtemel bir haçlı ittifakına dâhil etmeyi amaçlarken diğer taraftan da İstanbul Patriği'nin Osmanlı yönetimi altında olmasını gerekçe göstererek Rus Ortodoks Kilisesini kendi etki alanına almayı hedeflemiştir. Bu nedenle Papa XIII. Gregorius tarafından 1581 yılında Moskova'ya gönderilen papalık elçisi, Çarı papalık önderliğinde Hıristiyanların düşmanlarına karşı birlik oluşturmaya davet etmiştir. Daha önce de belirtildiği üzere Osmanlıya karşı oluşturulması muhtemel haçlı ittifakının içerisine Rusların da dâhil edilmesi, Çarın papanın öncülüğünü kabul etmesi şartına bağlanmıştı. Bu nedenle Papalık elçisi Çar İvan’ı bu konuda ikna etmeye çalışmış, hatta papanın öncülüğünü kabul ettiği takdirde sadece Kiev değil aynı zamanda İstanbul tahtının da kendisine verileceğini taahhüt etmiştir. Papalık elçisinin bu teklifini değerlendiren Çar, kilise konseyi ve Moskova metropolitinin onayı

\footnotetext{
Nikonov, “Russkaya Pravoslavnaya Tserkov i Rim," s. 29.

15 V. İ. Garadj, Protestantizm, İzdatelstvo Politicheskoy Literaturi, Moskova, 1971, s. 15-16.
} 
olmadan böyle bir karar almasının imkânsız olduğunu belirterek ruhbanları devreye sokmuştur. ${ }^{16}$ Çar İvan'ın ölümünü müteakiben yeniden harekete geçen Papa VIII. Klement (ö. 1605) 1594 yılında Moskova'ya çeşitli hediyelerle birlikte Rusçayı da iyi bilen bir papaz göndermek suretiyle Rusya'yı muhtemel haçlı ittifakına katılmaya davet etmiş̧ir. Papa'nın bu girişimi de inanç konusu yüzünden istenilen sonucu doğurmamıştır. ${ }^{17}$ XVI. yüzyılın sonuna doğru Katolik Polonya' nın giderek güçlenmesi ve Osmanlının artık eskisi kadar tehdit oluşturmaması Papalığın Rusya'ya olan bakış açısında değişikliklere yol açmıştır. ${ }^{18}$ Nitekim daha önceleri Rus yönetimi üzerinden siyasi ve dini amellerini hayata geçirmeyi amaçlamışken XVI. yüzyıldan itibaren Rus Ortodoks tebaaya yönelik misyonerlik faaliyetlerine hız verilmiştir.

\section{Düzmece Çar Dimitri ve Papalık}

Görüldüğü kadarıyla Roma papalarının öteden beri uygulaya geldikleri Rus yöneticileri üzerinde etkin olma çabaları istenilen sonucu doğurmamıştır. Özellikle Çar Korkunç İvan'la birlikte siyasi ve coğrafi açıdan daha da güçlenen bir Rusya, Papaların Rus Kilisesini kendisine bağlama girişimlerini boşa çıkarmıştır. Papalık kurumunun özellikle İstanbul'un fethedilmesini müteakiben Çarlık Rusyasını hem siyasi hem de dini açıdan kendi etki alanına çekme gayreti içerisinde olduğu görülmektedir. Yukarıda da bahsedildiği üzere papalar bir taraftan Osmanlı karşıtı muhtemel bir haçlı ittifakı içerisinde Rusya'nın da yer almasını isterlerken diğer taraftan bunun gerçekleşebilmesini Katolikliğin benimsenmesine bağlamışladır. Nitekim Papa XIII. Gregorius, Çar İvan'a İstanbul'un krallığını vaat ederken o tahta bir Ortodoks değil de Katolik inancına mensup birisi olarak oturmasını önermiştir. Bu çerçevede Rus çarlarının Osmanlı karşıtı bir ittifaka sıcak baktıkları ancak inanç konusunda asla taviz vermedikleri görülmektedir. Ancak 1600'lü yılların başlarında meydana gelen birtakım gelişmeler dönemin Papası VIII. Klement'i harekete geçirmiştir. Zira Çar I. Fyodor'un 1598 yılında ölmesi ve yerine geçecek bir varisinin olmaması, ülkede taht kavgalarının yaşanmasına yol açmıştır. Böyle bir ortamda sahneye Korkunç İvan'ın

\footnotetext{
16 V. Nikonov, "Russkaya Pravoslavnaya Tserkov i Rim," Jurnal Moskovsky Patriarkhi, 4/1949, s. 27.

17 Tolstoy, Rimsky Katolisizm v Rossii, I, s. 74-75.

18 Zonova, Rossiya i İtaliya: Istoriya Diplomaticheskih Otnosheniy, s. 15.
} 
Dinin Siyasete Etkisi Bakımından Vatikan-Moskova İlişkileri: Çarlık Rusyası Örneŏi oğlu olduğuna inanılan/iddia edilen Düzmece Dimitri'nin ${ }^{19}$ (ö. 1606) çıkması bir fırsat olarak değerlendirilmiştir. Polonya himayesine sı̆̆ınan ve buradan kendisine taraftar devşirmeye çalışan Dimitri, Papa VIII. Klement'in dikkatinden kaçmamıştır. ${ }^{20}$ İlk başlarda bu konuya fazla önem atfetmeyen Papa, Dimitri'nin Katolikliğe meylettiğini öğrenince daha fazla kayıtsız kalamamıştır. ${ }^{21}$ Bu çerçevede Polonya kralı ve papalık elçilerinin yoğun temasları sonucu Dimitri Katolikliği kabul etmiş ve tahta oturduğu takdirde Floransa anlaşmasına harfiyen uyacağını beyan etmiştir. Papaya verilen bu taahhüt sonrası askeri açıdan desteklenen Dimitri, 1605 yılında Moskova'ya girerek tahta oturmayı başarmıştır. İlk iş olarak Rus Patrik İov'u (ö. 1607) görevinden azleden Dimitri, yerine Yunan asıllı Ignatius'u (ö. 1620) Moskova Patriği olarak atamıştır. ${ }^{22}$

Katolikliği benimseyen Dimitri'nin Moskova tahtına oturması, Papa VIII. Klement açısından bir zafer olarak görülmüştür. Nitekim Rus Ortodoks Kilisesi'ni papalığın etkisi altına alma konusunda daha önce hiç bu denli başarı elde edilememişti. Ancak Papa VIII. Klement, Dimitri'den istenilen başarıyı göremeden 1605 yılında ölmüş, yerine gelen Papa V. Paul (ö. 1621) selefinin yolundan giderek

19 Çar I. Fyodor'un 1598 yılında ölmesini müteakiben tahta eniştesi Boris Godunov (ö. 1605) geçmiştir. Godunov'un tahta çıkmasını gayri kanuni sayan Düzmece Dimitri, kendisinin yasal varis olduğunu zira Korkunç İvan'ın bir kaza sonucu 1591 yılında öldügüu düşünülen küçük yaştaki oğlu Dimitri İvanoviç olduğunu öne sürmüştür. Nitekim bu dönemlerde halk arasında Dimitri'nin mucizevi bir biçimde ölümden kurtulduğuna ilişkin bir inanç da söz konusudur. Dolayısıyla henüz 1602 yılında kendisinin Prens Dimitri olduğunu öne süren düzmece Dimitri, takibe maruz kalınca Litvanya'ya kaçmış oradan da Polonya'ya geçmiştir. Papa ve Polonya krallığının da desteğiyle bir ordu toplamayı başaran Dimitri, 1604'ün sonlarında Rusya sınırlarını geçerek Moskova'ya doğru ilerlemeye başlamıştır. 1605 yılında Çar Godunov'un ani ölümü sonucu Moskova'ya girmeyi başaran Düzmece Dimitri, kendisini Rusya Çarı ilan etmiştir. Tahta geldikten kısa bir zaman sonra Dimitri'nin Korkunç İvan'ın oğlu oluşunun düzmece olduğu fikri yaygınlık kazanmaya başlamış ve Rus geleneklerine aykırı birtakım kararlar alması halk arasında tedirginliğe yol açmıştır. 1606 yılında bir darbe sonucu öldürülen Dimitri, Rus tarihine Düzmece Dimitri olarak geçmiştir. Bkz. V. İ. Ulyanovsky, Rossiyskie Samozvantsi: Lijdmitriy I, Libid, Kiev, 1993, s. 44-47. Ayrica Bkz. A. N. Bokhanov, M. Gorinov, İstoriya Rossii s Drevneyshkh Vremen do Kontsa XX veka, Stanovlenia Rossiyskogo Tsentralizovannogo Gosudarstva, Moskova, 1996, s. 607-608.

V. Kozlyakov, Ljedmitriy I, Moladaya Gvardiya, Moskovai 2009, s. 7.

22 Nikonov, "Russkaya Pravoslavnaya Tserkov i Rim," s. 31-32. 
Dimitri'yle yakından ilgilenmeye devam etmiştir. Örneğin Papa V. Paul, Moskova'da bulunan papalık kardinaline yolladığı bir mektubunda şöyle yazmıştır:

Eğer Dimitri Katolik inancına bağlı kalmaya devam ederse zaman içerisinde Rusları kutsal Katolik kilisesinin himayesine almamız mümkün olacaktır. Zira bildiğimiz üzere bu halk kendi çarlarına çok bağlıdır. ${ }^{23}$

Papa V. Paul, süreci hızlandırmak maksadıyla Dimitri'ye gönderdiği elçiler vasıtasıyla zaman kaybetmeksizin Floransa anlaşmasına uymasını talep etmiş, ancak Dimitri böyle bir karar için ortamın müsait olmadığını belirterek ısrarlı davranıldığı takdirde tahtı kaybetme tehlikesiyle karşı karşıya kalacağını belirtmiştir. Nitekim Dimitri'nin iç ve dış politikada Polonya'nın etkisinde kalması, Ortodoks inancına ters düşen birtakım uygulamaların gündeme gelmesi, birçok boyar ${ }^{24}$ ona karşı cephe almaya sevk ederken, halkın Dimitri'ye olan güvenini de önemli ölçüde zedelemiştir.

1606 yılının Nisan Mayıs ayları içerisinde durumun Dimitri açısından çok daha kritik bir hal aldığı görülmektedir. Zira harekete geçen Boyar Vasili İvanoviç Şuyski, (ö.1616) Moskova halkını Dimitri'ye karşı kışkırtmaya başlamıştır. Bu çerçevede Dimitri'nin halkı kandırdığı ve Ortodoksluk inancı yerine Katolikliği benimsediği konusunda algı oluşturmaya çalışmıştır. Nihayet 17 Mayıs 1606 tarihinde Şuyski öncülügünde hareket eden Boyarlar, halkın da desteğiyle Çar Düzmece Dimitri'yi tahttan indirmeyi başarmıştır. ${ }^{25}$ Kuşkusuz Dimitri'nin tahttan indirilmesi ve idam edilmesi Doğu Rusya için birtakım planları olan Papaları hayal kırıklığına uğratmıştır. Dimitri'nin bir isyanla devrilmesinden sonra onun düzmece ve Ortodoksluk düşmanı olduğu algısı Rus tarih kitaplarında yaygınlık kazanmıştır. Özellikle Dimitri'nin "lanetli Katolik inancını yaymayı amaçladığı" savı çok daha belirgin hale gelmiştir. ${ }^{26}$ Ancak bu savın Rus Ortodoks Kilisesi tarafından bilinçli bir biçimde canlı tutulduğunu belirtmekte yarar vardır. Nitekim İstanbul'un fethiyle birlikte Ortodoksluğun merkezinin Moskova'ya aktarıldığı tezinin

23 Tolstoy, Rimsky Katolisizm v Rossii, I, s. 81.

24 Boyar: Rus Asilzade, Slav Soylusu, Bkz. D. Mehmet Doğan, Büyük Türkçe Sözlük, İz Yayınevi, 1996, s 159.

25 Kozlyakov, Ljedmitriy I, s. 121-122.

26 V. Nikonov, "Russkaya Pravoslavnaya Tserkov i Rim," Jurnal Moskovsky Patriarkhi, 7/1949, s. 45. 
Dinin Siyasete Etkisi Bakımından Vatikan-Moskova İlişkileri: Çarlık Rusyası Örneŏi

Rus Kilisesi tarafından işlendiği bir ortamda, Papanın bölgeye yönelik girişimleri, Rus ruhban sınıfını son derece rahatsız etmiştir. Dolayısıyla düzmece Dimitri, Rus tarihinde adeta bir Katolik misyoner gibi tanıtılmaya çalışılmıştır. Kuşkusuz dönemin papaları ortaya çıkan bu fırsatı kendi lehlerine kullanmayı ve Dimitri’yi çeşitli vesilelerle destekleyerek Rus toplumunda Katolik inancını yaygınlaştırmayı hedeflemişlerdir. Ancak unutulmamalıdır ki Dimitri de tahta geçmek için Papa başta olmak üzere Polonya yönetimini kendi çıkarları çerçevesinde kullanmaktan geri durmamıştır.

\section{Rusya'yı Katolikleştirme Çabaları}

Papa ve Polonya kralının büyük umut beslediği düzmece Dimitri'nin henüz istenen adımları atamadan tahttan indirilmesi, Katolik kilisesini hayal kırıklığına uğratmıştır. Ancak ilginç bir biçimde Papaların Rus Ortodoks Kilisesi'ni kendi etki alanları altına alma girişimleri nihayete ermemiştir. Bu çerçevede XVII. yüzyılın ilk çeyreğinden itibaren Moskova başta olmak üzere ülkenin çeşitli eyaletlerine farklı meslekler adı altında misyonerlerin nüfuz etmeye çalıştığı görülmektedir. Katolik ve Cizvitlerin sayılarının ülkede giderek artış göstermesi mabet sorununu da beraberinde getirmiştir. Ancak Çar I. Mihail, (ö. 1645) Katoliklerden gelen talebe ve Fransa elçisinin ricasına rağmen Moskova'da herhangi bir Katolik mabedinin açılmasına onay vermemiştir. Diğer taraftan Katolikliğin misyonerler vasıtasıyla ülkeye nüfuz etmeye çalıştığını savunan Rus Ortodoks Kilisesi, çardan Katolik ve Cizvit misyonerlerin ülkeye girişini yasaklaması talebinde bulunmuştur. Bu çerçevede XVII. yüzyılın sonuna kadar Çarlık Rusyası sınırları içerisinde Katoliklerin ne uzun süreli ikamet etmelerine ne de kilise inşa etmelerine müsaade edilmemiştir. ${ }^{27}$

Papalık, Çarlık Rusya'sının devlet kademelerinde meydana gelen değişmelerle birlikte Rus Ortodoks Kilisesi içerisinde ortaya çıkan gelişmeleri de yakından takip etmiştir. Bu çerçevede Moskova Patriği Nikon'un (ö. 1681) kendisini adeta bir “Papa” olarak görmesi ve Moskova'nın Ortodoks dünyasına öncülük etmesi için birtakım girişimlerde bulunması Katolik dünyasını endişeye sevk etmiştir. ${ }^{28}$ Nitekim Patrik Nikon, Roma Papalarının asırlardan beri uygulamaya çalıştıkları Rus Ortodoks Kilisesi'nin Papalık himayesi altına

27 Tolstoy, Rimsky Katolisizm v Rossii, I, s. 98-99.

28 Şir Muhammed Dual, "Rusya Federasyonu'nda Milli ve Dini Kimliğin Yükselişi," Akademik Incelemeler Dergisi, Cilt 8, Sayı 2, 2013, s. 210 
alınması tezinin tersine Slav halklarının tümünü bir çatı altında toplamayı öngörürken İstanbul'u da Müslümanların elinden kurtararak yeniden Ortodoks dünyaya katmayı hedeflemiştir. İlk başlarda Çar I. Aleksey'in (ö. 1679) teveccühünü kazanan Nikon, dini otoritenin laik yönetimin üzerinde olduğunu savunmuş ve kendisini adeta çardan daha etkin bir konuma yerleştirmiştir. ${ }^{29}$ Ayrıca o, Ortodoks dünyasına hitap edebilmek için kilisede kullanılan ritüelin standartlaştırılması yoluna gitmiştir. Nikon'un Ortodoks dünya üzerinde etkin olma girişimi birtakım iç ve dış çevreleri harekete geçirmiştir. Çar I. Aleksey, ilk aşamada Nikon'u desteklemişse de daha sonraki süreçte onun iktidar hırsından rahatsızlık duyarak görevden azline karar vermiş̧ir. Çar Aleksey, Nikon'un yargılanması için bir komisyon kurmuş ve bu komisyona diğer Ortodoks kiliselerden temsilciler davet etmiştir. Rus araştırmacı V. Nikonov, kaleme aldığı "Rus Ortodoks Kilisesi ve Roma" başlıklı makalesinde Çar Aleksey'in Patrik Nikon'u yargılamak üzere oluşturduğu komisyona dönemin Gazze Metropoliti P. Ligaridi'nin (ö. 1678) papalık casusu olarak katıldığını ve Nikon'a karşı en sert muhalefeti onun yaptığını yazmaktadır. Nikonov, metropolit Ligarid'den bahsederken onun "Ortodokslarla Ortodoks, Katoliklerle de Katolik gibi" davrandığının altını çizmektedir. Ayrıca Patrik Nikon'a karşı sert muhalefetinden dolayı Çarın güvenini kazanmayı başardığını ve bu sayede uzun müddet Moskova'da kalarak birtakım faaliyetlerde bulunduğunu belirtmektedir. ${ }^{30}$ Ortodoks dünyanın lideri ve birleştiricisi olma yolunda bazı adımlar atan ancak daha fazla ileri gitmeden engellenen Patrik Nikon'un bertaraf edilmesi, papalık tarafından memnuniyetle karşılanmıştır. Nikon'un görevden uzaklaştırılmasından sonra harekete geçen papalık, kiliselerin birleşmesini öngören teklifi yeniden gündeme getirmişse de olumlu sonuç alınamamıştır.

Katolikliğin Rusya topraklarında yaygınlık kazanması için misyonerlik faaliyetlerine hız veren papalık, 1680'li yıllardan itibaren çok sayıda Katolik misyoneri Rusya topraklarına intikal ettirmiştir.

29 Nikonov, "Russkaya Pravoslavnaya Tserkov i Rim," s. 49.
30 Nikonov, "Russkaya Pravoslavnaya Tserkov i Rim," s. 51. 
Dinin Siyasete Etkisi Bakımından Vatikan-Moskova İlişkileri: Çarlık Rusyası Örneŏi

$\mathrm{Bu}$ çerçevede Katoliklere mahsus ilk ibadet evi 1687 yılında Moskova'da faaliyete geçmiştir. ${ }^{31}$ Rusya'ya yönelik bu misyoner faaliyetler, Rus Ortodoks Kilisesini birtakım önlemler almaya itmiş, 1689 yılında varılan bir kararla Katolik ve Cizvitlerin sınır dışı edilmeleri gündeme gelmiştir. Bu çerçevede ülkede faaliyet yürüten Katolik ve Cizvit misyonerler sınır dişı edilirken, Protestan ve reformist Hıristiyanlara dokunulmamıştır. ${ }^{32}$ Katoliklerle birlikte Cizvitlerin de hedef alınmasının asıl sebebi onların Papalığa bağlı hareket ediyor olmalarıdır. Bu durumdan rahatsız olan Polonya, Moskova'ya bir elçi göndererek Cizvitlere yönelik alınan karardan vazgeçilmesini istemiştir. Yapılan görüşmeler sonucu Moskova genelinde sadece bir Katolik rahibin ikamet etmesine onay verilmiştir. ${ }^{33}$

Çar I. Petro'nun (ö. 1725) Batıya yönelmesi ve devletin çeşitli kademelerinde köklü reformları hayata geçirmesine paralel olarak papalığın Rusya'ya yönelik misyon faaliyetlerinde bir artış söz konusu olmuştur. Dolayısıyla Katolik misyonunun Rusya'nın Batı ile olan ilişkilerine paralel oranda değişkenlik arz ettiği gözlemlenmiştir. Örneğin Petro ile birlikte Rusya'da daha rahat hareket etme fırsatı bulan Cizvitler, 1719 yılında Macaristan'la Rusya ilişkilerinin kötüye gitmesini müteakiben siyasete müdahil oldukları gerekçesiyle sınır dışı edilmişlerdir. ${ }^{34}$ Bir yandan Katolik kilisesine ve onun Rusya'ya yönelik misyonerlik faaliyetlerine karşı ciddi mücadele verilirken diğer taraftan Kiliselerin birleştirilmesi girişimleri de hiz kesmeden devam etmiştir. Örneğin Çar I. Petro'nun 1717 Paris seyahati sırasında bu konu gündeme getirilerek Petro'dan destek istenmiş, ancak Petro, devlet işleriyle uğraşmaktan bu konulara zaman ayıramayacağını, arzu edecekleri takdirde Rus ruhban sınıfıyla irtibata geçebileceklerini belirtmiştir. ${ }^{35}$ Dolayısıyla Batı'nın bu girişiminin de sonuçsuz kaldığ 1 görülmektedir.

\footnotetext{
31 Germogen, "Papstva i Pravoslavnaya Tserkov," Jurnal Moskovsky Patriarkhi, 4/1948, s. 35.

32 Nikonov, "Russkaya Pravoslavnaya Tserkov i Rim," s. 55.

33 Tolstoy, Rimsky Katolisizm v Rossii, I, s. 119.

34 Nikonov, "Russkaya Pravoslavnaya Tserkov i Rim," s. 57.

35 Tolstoy, Rimsky Katolisizm v Rossii, I, s. 166.
} 


\section{Katolik Misyonunun Başarısızlıkla Sonuçlanması}

Çarlık Rusya'sının zamanla güçlenerek bir imparatorluğa dönüşmesi, beraberinde yeni coğrafyaların işgaline yol açmıştır. Bu çerçevede 1772 yılında bir kısım Polonya toprağının (şimdiki Beyaz Rusya sınırları içerisinde kalan bir bölge) Rusya'nın kontrolüne geçmesiyle ${ }^{36}$ birlikte bir buçuk milyon civarında Cizvit ve Katolik tebaa, Rusya'nın yönetimi altına girmiştir. Böyle bir ortamda Çariçe II. Katerina, (ö. 1796) bir taraftan Katolik ve Cizvit tebaanın Rus yönetiminin bilgisi ve kontrolü dâhilinde dini faaliyetler yürütmesine onay verirken, diğer taraftan da Papalığın bölgede var olan etkinliğini azaltmaya çalışmıştır. Ayrıca Katolik kilisesine ait manastırların müsadere edilmesini isterken bazılarının da kapatılmasını kararlaştırmıştır. Katerina'nın bu girişimleri papalık nezdinde Rusya'da Katolikliğin yok edilmesi olarak görülmüş ve şiddetli bir biçimde karşı çıkılmıştır. ${ }^{37}$ Çariçe II. Katerina, dış güçlerin özellikle de papalığın Katolikler üzerinden Rusya'nın iç işlerine karışmasına göz yummamış, Papa'nın itirazına rağmen yönetimi altındaki Katolik tebaayı kontrol etmek ve papalığın etkisinden kurtarmak için ciddi gayret sarf etmiştir. Bu çerçevede yönetimi altındaki Katolik cemaat üzerinde siyasi açıdan etkin olmaya çalışmıştır.

XVI. yüzyılın ortalarına kadar Katolik inancına mensup güçlü bir Polonya krallığının varlığı, Papalığın Çarlık Rusya'sına yönelik birtakım faaliyetler yürütmesine imkân tanımıştır. Bunlardan en önemlisi Rus Ortodoks Kilisesi'nin Papa'nın üstünlük ve öncülügünü kabul etmesine yönelik girişimlerdir. Ancak bu tarihten itibaren güçlenen ve giderek etki alanını genişleten bir Rusya'nın ortaya çıkması, durumun tersine çevrilmesine neden olmuştur. Nitekim daha önce de bahsedildiği üzere, 1772 yılında Polonya topraklarının bir bölümünün Rusya'nın kontrolüne geçmesiyle birlikte bir buçuk milyon civarında Katolik tebaa Ortodoks Rusya'nın yönetimi altına girmiştir. Sınırlarını genişletmeye devam eden Rusya, 1783 yılında Gürcistan'la bir anlaşma yaparak Hıristiyan Gürcü halkını Çarlık Rusya'sının koruması altına almıştır. Yine 1774 yılında Osmanlı'nın Balkanlar üzerindeki etkisini kırmak suretiyle bölgedeki Hıristiyan

\footnotetext{
36 V. Nikonov, "Russkaya Pravoslavnaya Tserkov i Rim," Jurnal Moskovsky Patriarkhi, 11/1949, s. 40.

37 D. M. Tolstoy, Rimsky Katolisizm v Rossii, Tom Pervy, Petersburg, II, 1876, s. 1-9.
} 
Dinin Siyasete Etkisi Bakımından Vatikan-Moskova İlişkileri: Çarlık Rusyası Örneği tebaanın hamisi konumuna yükselmiştir. ${ }^{38}$ Ayrıca 1795 yılında Polonya topraklarının yeniden paylaşılması sonucu üç yeni Katolik bölge Rusya'nın kontrolüne geçmiştir. ${ }^{39}$ Dolayısıyla Rusya artık, Papalık açısından ciddi bir tehlike arz edeceği endişesini taşımak yerine etki alanında bulunan Katolik tebaayı kendi çıkarları doğrultusunda kullanmaya ağırlık vermiştir. $\mathrm{Bu}$ çerçevede Katolik ve Cizvitler üzerinde devlet kontrolünü sağlamayı başaran II. Katerina'nın 1796 yılında ölmesini müteakiben yerine Ortodoks geleneğe sıkı sıkıya bağlılığıyla bilinen oğlu Çar I. Pavel (ö. 1801) geçmiştir.

Ülke içi siyasette annesinin politikalarına aykırı bir tutum sergilemişse de dış politikada gözle görülür bir farklılı̆̆a meyletmemiştir. Her ne kadar ideolojik olarak Cizvitlere karşı bir tutum içerisinde olmuşsa da Batı aydınlanma düşüncesine karşı çıktıklarından dolayı onlara tolerans göstermiştir. Ancak 1815 yılı itibarıyla özellikle Cizvitlere yönelik baskılar artarken 1820'de Rusya genelindeki tüm Cizvit dini yapılanmaları tasfiye edilmiştir. ${ }^{40}$ Bu süreç Ukrayna' nın kuzey batısı dâhil birçok coğrafyanın yeniden Rus Ortodoks Kilisesi'nin etkisi altına girmesinin yolunu açmıştır. Papalık, durmadan genişleyen ve özellikle Cizvit ve Katoliklere karşı olumsuz politika izleyen Rusya'ya karşı söylemlerini sertleştirmiştir. Hatta 1877 de patlak veren Türk-Rus savaşı sırasında Türk ordusunu kutsayan papalık, Rusya karşıtı bir politika izlemiştir. ${ }^{41}$

XIX. yüzyılın ikinci yarısından itibaren K. Marx’ın (ö. 1883) geliştirdiği sosyalizm teorisinin etkisiyle ortaya çıkan işçi hareketleri, kuşkusuz papalık tarafından dikkatle takip edilmiştir. Özellikle XIX. yüzyılın sonlarına doğru Batıda ciddi dalgalanmalara neden olan sosyal hareketlilik papalığı birtakım tedbirler almaya itmiştir. Örneğin Katolik kilisesi çevrelerince ilk "sosyal reformcu" ve "işçi çıkarlarının savunucusu" olarak lanse edilen dönemin papası XIII. Leo, (ö. 1903) 1891 yılında işçilerin haklarının gözetilmesine ilişkin yayınladığı bir beyanatla dikkat çekmektedir. Papa bu beyanatla bir

\footnotetext{
38 Bkz. A. S. Orlov ve Diğerleri, Rusya Tarihi, Prospekt Yayınları, Moskova, 2001, 140-141.

39 V. Nikonov, "Russkaya Pravoslavnaya Tserkov i Rim," Jurnal Moskovsky Patriarkhi, 11/1949, s. 45.

40 Nikonov, "Russkaya Pravoslavnaya Tserkov i Rim," s. 50-51.

41 Germogen, "Papstva i Pravoslavnaya Tserkov," s. 34.
} 
anlamda işçilerin beğenisini kazanmayı ve onları sosyalist oluşumlardan uzak tutmayı hedeflemiştir. Zira Papa XIII. Leo'nun Marksizm ve Sosyalizmi kilise düzeni açısından son derece tehlikeli ve yok edilmesi elzem bir hareket olarak gördüğü muhakkaktır. Bu çerçevede Papa XIII. Leo'nun 1888 yılında Çar III. Aleksandr'a (ö. 1894) sosyalizme karşı ortak mücadele teklifinde bulunduğu bilinmektedir. Buna benzer bir teklif 1903'te Almanya imparatoru II. Wilhelm'e (ö. 1941) yapılmıştır. Yine aynı şekilde 1890 'da İtalyan ruhanilerine yönelik beyanatında Sosyalizmin çok büyük bir tehdit içerdiğini, bu belanın bertaraf edilmesi için devletin tüm kurumlaryyla ortak bir zeminde buluşulması gerektiğini söylemektedir. ${ }^{42}$

Papalığın Rusya karşıtı tutumu I. Dünya Savaşı sırasında da devam etmiştir. Özellikle 1914 yılında yeni papa seçimleri için düzenlenen kardinaller toplantısı, Fransa ve Almanya arasında mücadele arenasına dönüşmüştür. I. Dünya Savaşında karşı karşıya gelen her iki cephenin tarafları, papalığı dolayısıyla Katolik dünyayı kendi cephelerine çekmeye gayret sarf etmişlerdir. Alman kardinallerin temel argümanı, Ortodoks Rusya'nın savaşı kazanması halinde Katolikliğin sona ereceği üzerine olmuştur. Dolayısıyla itilaf devletlerinin mukavemetini güçlendirmek için seçilecek yeni papanın Alman-Avusturya ekolüne yakın olması elzem görülmüştür. ${ }^{43} \mathrm{Bu}$ çerçevede 1914 yılında papalık görevine Alman kökenli XV. Benedictus (ö. 1920) seçilmiştir. I. Dünya savaşı boyunca Almanya'dan yana tavır almasiyla bilinen papanın Alman Katoliklerin etkisi altında olduğu görülmektedir. Özellikle 1917'de sosyalizmi savunan Bolşeviklerin iktidara gelmesi, Papa XV. Benedictus'u endişeye sevk etmiş, Ağustos 1917 tarihli beyanatında dünyayı Almanya'nın yanında Sovyet Rusya'sına karşı birlikte mücadeleye çağırmıştır. ${ }^{44}$ Buna benzer çıkışların ilerleyen tarihlerde tekrarlandığını söylemek mümkündür. Örneğin Papa XV. Benedictus 23 Ocak 1918 tarihli bir diğer beyanatında sosyalizm tehlikesine işaret ederek dünya devletlerini Rusya'ya müdahil olmaya çağırmıştır. Ayrıca 1920-22 yılları

42 M. Şeynman, Vatikan Vo Vtoroy Mirovoyi Voyni, İzdatelstvo Akademii nauk SSSR, Moskova, 1951, s. 10-11.

43 M. Sheynman, Vatikan Mejdu Dvumya Mirovimi Voynami, İzdatelstvo Akademii Nauk SSSR, Moskova, 1948, s. 14.

44 Şeynman, Vatikan Vo Vtoroy Mirovoyi Voyni, s. 12. 
Dinin Siyasete Etkisi Bakımından Vatikan-Moskova İlişkileri: Çarlık Rusyası Örneŏi arasında Rusya'da cereyan eden iç savaşta Bolşeviklere karşı mücadele eden muhalifleri desteklemekten çekinmemiştir. ${ }^{45} \mathrm{Bu}$ çerçevede Sovyetler Birliği dönemi boyunca Batı Dünyası Vatikan üzerinden Rusya ile mücadele etmeye devam etmiştir. Özellikle II. Dünya Savaşı sonrasında Sovyetlerin Ukrayna'da mevcut Grek Katolik Kiliselerine ${ }^{46}$ yönelik tasfiye politikaları Vatikan'ın sert tepkisine yol açmıştır.

\section{Sonuç}

451 Kadıköy Konsili'yle birlikte belirginlik kazanan ve nihayetinde 1054 yılında Hıristiyan dünyasının resmen Batı ve Doğu olmak üzere ikiye bölünmesiyle devam eden öncülük ve üstünlük mücadelesi, çeşitli evrelerden geçerek günümüze kadar süregelmiştir. Bu aslında Doğu ile Batının, Grek ile Latin kültürünün Hıristiyanlık adı altında egemenlik mücadelesinin bir yansıması olarak karşımıza çıkmaktadır. Bu mücadele her ne kadar din/dogma temeline dayandırılmışsa da siyasi/politik ve etik boyutun daha etkin olduğu muhakkaktır. Dolayısıyla giriş bölümünde de alıntılandığı üzere Yeni Ahit metinlerinde kilisede birlik ve bütünlüğü ön plana çıkaran pasajlara rağmen, tarihi süreç boyunca birden fazla bağımsız kilise oluşumu ortaya çıkmıştır. Zaman içerisinde belirginlik kazanan Katolik ve Ortodoks ayrışması her iki kiliseyi alan mücadelesine sevk etmiştir. Bu çerçevede Doğu Roma Kilisesi'nin dini ve siyasi etkinliğini arttırmak maksadıyla Güney Avrupa coğrafyacına yönelmesi, Batı Roma Kilisesi'ni harekete geçirmiştir. Bu bağlamda söz konusu coğrafyaya yönelik misyonerlik faaliyetlerine ağırlık veren Katolik Kilisesi özellikle Romanya ve Polonya başta olmak üzere birçok Doğu Avrupa ülkesinin Katolikliği benimsemesine muvaffak olmuştur. Ancak Rusların özellikle siyasi ve coğrafi nedenlerden dolayı Ortodoksluğu benimsemeleri Katolik Kilisesi ve dönemin papaları tarafından Doğu Roma'ya karşı bir yenilgi olarak görülmüş ve durumu kendi lehlerine çevirmek için çalışmalara hız verilmiştir.

45 N. Plesetskiy, “Vatikan i Ego Politika," Jurnal Moskovsky Patriarkhi, 10/1948, s. 42.

461596 yılında Kiev Metropolitliğinin önemli bir kısmı, Metropolit Michel Rohoza (ö.1599) önderliğinde Brest'de konsey toplayarak Roma Papa'sının hukuki üstünlüğünü tanıma kararı almıştır. Birliğin almış olduğu kararın etkisiyle ilerleyen dönemlerde Grek Katolik Kilisesi Ukrayna'nın batı kesimlerinde konumunu güçlendirmeyi başarmıştır. Bkz. M. V, Dimitriev, Brestskaya Uniya 1596 g. İ Obşestvenno-Politiçeskaya Borba na Ukraine i v Belorussii v Kontse XVI-Pervıy Polovine XVII v, Moskova, Çast II, İzdatelstvo İndrik, 1996, s. 88. 
Bu bakış açısı zamanla papalık misyonunun bir parçasına dönüşmüştür.

Bu süreç özellikle XV. yüzyılın başlarından itibaren artan Osmanlı tehdidine karşı Doğu Roma'nın Floransa Konsili'nde Papanın üstünlüğünü kabul etmesiyle birlikte hız kazanmıştır. 1453 yılında Doğu Roma'nı tarih sahnesinden silinmesi ve Ortodoksluk merkezinin Moskova'ya kaydırılması, Papalığın Rusya'ya daha fazla önem atfetmesine neden olmuştur. Özellikle Batıya doğru ilerleme kaydeden Osmanlı'nın durdurulması hususunda Çarlık Rusya'sıyla ittifak arayışı içerisinde olan papalık, bu ittifakın gerçekleşebilmesini kendi üstünlüğünün Rus Ortodoks Kilisesi tarafından resmen kabulüne bağlamıştır. Ancak Papalığın tüm bu çabaları giderek güçlenen ve XVIII. yüzyıldan itibaren bir imparatorluğa dönüşen Çarlık Rusyası tarafından siyasi bir baskı ve Rus egemenliğinin ihlali olarak görülmüş ve buna karşı milli bir refleks geliştirilmiştir. İşte tüm bu gelişmeler ve Papalığın uzun yıllardan beri yürüttüğü politikaların başarısızlıkla sonuçlanması Katolik Kilisesi'ni Ortodoks Rusya'ya karşı pozisyon almaya ve her firsatta Rusya karşıtı politika üretmeye iten temel faktör olmuştur.

\section{Kaynakça}

Bokhanov A. N., Gorinov M., İstoriya Rossii s Drevneyshkh Vremen do Kontsa XX veka, Stanovlenia Rossiyskogo Tsentralizovannogo Gosudarstva, Moskova, 1996.

Chrysostom John., Tvoreniya (Creations), c. X, Petersburg, 1904.

Çoban Bekir Zakir, geçmişten günümüze Papalık, İnsan Yayınları, İstanbul, 2009.

Episkop Germogen, “Papstva i Pravoslavnaya Tserkov," Jurnal Moskovsky Patriarkhi, 4/1948, s. 29-37.

Dualı Şir Muhammed., "Rusya Federasyonu'nda Milli ve Dini Kimliğin Yükselişi," Akademik İncelemeler Dergisi, Cilt 8, Sayı 2, 2013, s. 205222.

Garadj V. İ., Protestantizm, İzdatelstvo Politicheskoy Literaturi, Moskova, 1971.

Khrysostomos Yannis, Tvoreniya (Creations), c. X, Petersburg, 1904.

Lavrentevskaya Letopis, Laurentian Kronik, Rus Kronikler Koleksiyonu, II. Baskı, c. I, 1926-1928.

Nikonov V., "Russkaya Pravoslavnaya Tserkov i Rim,” Jurnal Moskovsky Patriarkhi, 3/1949, s. 21-29.

, "Russkaya Pravoslavnaya Tserkov i Rim," Jurnal Moskovsky Patriarkhi, 4/1949, s. 23-34. 
Dinin Siyasete Etkisi Bakımından Vatikan-Moskova İlişkileri: Çarlık Rusyası Örneği kovsky Patriarkhi, 7/1949, s. 45-60.

kovsky Patriarkhi, 11/1949, s. 37-51.

Orlov A. S. ve Diğerleri, Rusya Tarihi, Prospekt Yayınları, Moskova, 2001.

Papov O.M., Russkaya Tserkov v IX-XII veke, Prinyatie Hristianstva, Moskova, 1988.

Plesetskiy N., “Vatikan i Ego Politika," Jurnal Moskovsky Patriarkhi, 10/1948, s. 39-47.

Sheynman M., Vatikan Vo Vtoroy Mirovoyi Voyni, İzdatelstvo Akademii nauk SSSR, Moskova, 1951. -, Vatikan Mejdu Dvumya Mirovimi Voynami, İzdatelstvo Akademii nauk SSSR, Moskova, 1948.

Tatishev V. N., İstoriya Rossiyskaya, s Samih Drevneyshk Vremen, Kniga Tretiy, İmperatorsky Moskovsky Universitet, 1774.

Tolstoy D. M., Rimsky Katolisizm v Rossii, Tom Pervy, Petersburg, I, 1876. 1876.

Ulyanovsky V. İ., Rossiyskie Samozvantsi: Lijdmitriy I, Libid, Kiev, 1993.

Zonova T. V., Rossiya i İtaliya: İstoriya Diplomaticheskih Otnosheniy, Chast I, Moskova, 1998.

Şahmatov A. A., Razıskaniya o Drevneyşikh Russkih Letopisnıh Svodah, Petersburg, 1908. 


\section{MiLel VE NiHAL}

inanç, kültür ve mitoloji araştırmaları dergisi

Cilt/Volume: 11 Sayı/Number: 1 Ocak - Haziran / January - June 2014 ISSN: 1304-5482

Bu dergi uluslararası EBSCO HOST Research Databases veri indeksi ve TÜBITTAK-ULAKBİM Sosyal ve Beşeri Bilimler Veri Tabanı tarafından taranmaktadır.

\section{Sahibi / Owner}

Milel ve Nihal Eğitim, Kültür ve Düşünce Platformu Derneği adına Şinasi Gündüz

$$
\begin{gathered}
\text { Yazı İşleri Sorumlusu / Legal Representative } \\
\text { Yasin Aktay }
\end{gathered}
$$

\section{Editör / Editor}

Şinasi Gündüz

Editör Yrd. / Co-Editor

Cengiz Batuk

\section{Yayın Kurulu/ Editorial Board*}

Alpaslan Açıgenç, Ayaz Akkoyun, Yasin Aktay, Mahmut Aydın,

Cengiz Batuk, Şinasi Gündüz, İbrahim Kayan, Hakan Olgun, Necdet Subaşı,

\section{Burhanettin Tatar}

\section{Danışma Kurulu/Advisory Board}

Baki Adam (Prof. Dr., AÜ); Mohd. Mumtaz Ali (Prof. International Islamic U. Malezya); Adnan Aslan (Prof.Dr., Süleyman Şah Ü.); Kemal Ataman (Doç.Dr., Uludağ Ü.); Mehmet Akif Aydın (Prof. Dr., Marmara Ü.); Yılmaz Can (Prof. Dr., OMÜ); Ahmet Çakır (Doç. Dr., OMÜ); Mehmet Çelik

(Prof. Dr., Celal Bayar Ü.); Waleck S. Dalpour (Prof. University of Maine at Farmington); İsmail

Engin (Dr., Berlin); Cemalettin Erdemci (Prof.Dr. YYÜ); Tahsin Görgün (Prof.Dr., 29

Mayıs Ü.) Ahmet Güç (Prof.Dr., Uludağ Ü.); Recep Gün (Doç. Dr., OMÜ); Ö. Faruk Harman

(Prof.Dr., Mar.Ü.); Erica C.D. Hunter (Dr., Cambridge U.); Mehmet Katar (Prof. Dr., A.Ü.);

Mahmut Kaya (Prof. Dr., İ.Ü.); Sadık Kılıç (Prof.Dr., Atatürk Ü.); Şevket Kotan (Y.Doç.Dr., İ.Ü.); İlhan Kutluer (Prof.Dr., Mar. Ü.); George F. McLean (Prof. Catholic Univ., Washington DC); Ahmet Yaşar Ocak (Prof. Dr., Hacettepe Ü.); Jon Oplinger (Prof. University of Maine at Farmington); Ömer Özsoy (Prof.Dr., Frankfurt U.); Roselie Helena de Souza Pereira (Mestre em

Filofia-USP; UNICAMP Brasil); Ekrem Sarıkçıŏlu (Prof.Dr., SDÜ); Hüseyin Sarıŏlu (Prof.Dr.,

İÜ); Bobby S. Sayyid (Dr. Leeds U.); Mustafa Sinanoğlu (Prof.Dr., 29 Mayıs Ü.); Mahfuz Söylemez

(Prof.Dr. IÜ); Necdet Subaşı (Y.Doç.Dr., DİB); Bülent Şenay (Prof.Dr., UÜ); İsmail Taşpınar

(Prof.Dr. Mar.Ü.); C. Sadık Yaran (Prof.Dr., OMÜ); Ali Murat Yel (Prof.Dr., Fatih Ü.); Hüseyin Yılmaz (Doç.Dr., YYÜ); Ali İhsan Yitik (Prof. Dr., DEÜ)

* Soyadına göre alfabetik sıra / In alphabetical order

Kapak ve Sayfa Tasarımı / Cover \& Page Design

İnan Avc1

Baskı / Publication

Ladin Ofset - İstanbul, Mart 2015

2.Mat. Sit. 3 NB 15 Topkapı İstanbul / İsmail Tüz 02125012418

Yönetim Yeri / Administration Place

Milel ve Nihal Eğitim, Kültür ve Düşünce Platformu Derneği

Fevzipaşa Cad. Şehit Mehmet Sarper Alus Sok. No: 5, K.: 3, Tel: (0212) 5339731 Fatih/İstanbul www.milelvenihal.org e-posta: dergi@milelvenihal.org

Milel ve Nihal yılda iki sayı olarak altı ayda bir yayımlanan uluslararası hakemli bir dergidir. Milel ve Nihal' de yayımlanan yazıların bilimsel ve hukuki sorumluluğu yazarlarına aittir. Yayım dili Türkçe ve İngilizce'dir. Yayımlanan yazıların bütün yayın hakları Milel ve Nihal'e ait olup, yayıncının izni olmadan kısmen veya tamamen basılamaz, çoğaltılamaz ve elektronik ortama taşınamaz. Yazıların yayımlanı yayımlanmamasından yayın kurulu sorumludur. 


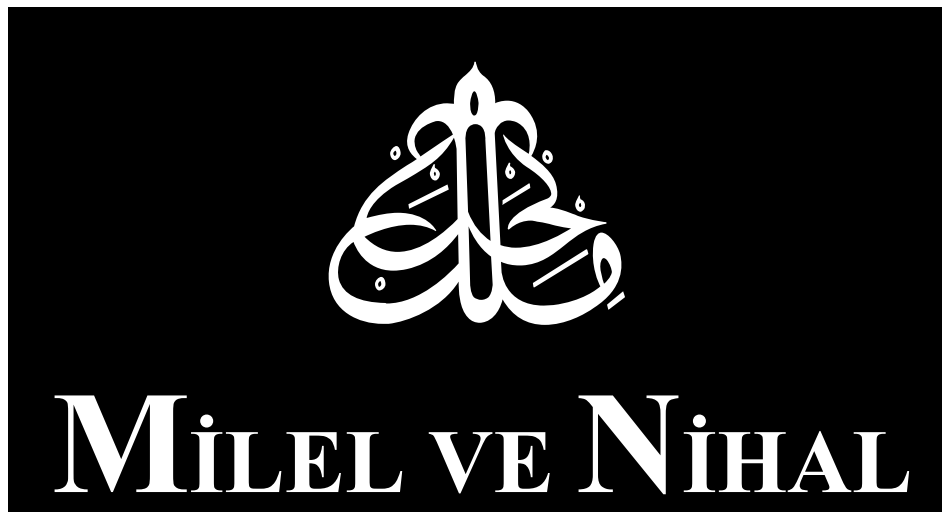

inanç, kültür ve mitoloji araştırmaları derogisi

ISSN: 1304-5482

Cilt/Volume: 11 Sayı/Number: 1

Ocak - Haziran / January - June 2014 